\title{
Zmienność czasowa i zróżnicowanie przestrzenne wielkości i tempa erozji klifu Zatoki Usteckiej w rejonie Orzechowa
}

\author{
Spatiotemporal differentiation of cliff erosion rate within the Ustka Bay near Orzechowo
}

\author{
Jerzy J. Frydel ${ }^{1 *}$, Lesław Mil'1, Tomasz Szarafin'1, Dorota Koszka-Maroń1, \\ Maria Przyłucka² \\ 1Państwowy Instytut Geologiczny - PIB, Oddział Geologii Morza, Gdańsk; * jerzy.frydel@pgi.gov.pl \\ 2Państwowy Instytut Geologiczny - PIB, Warszawa
}

\begin{abstract}
Zarys treści: $\mathrm{W}$ artykule przedstawiono próbę ilościowej i jakościowej oceny morfodynamiki fragmentu wysokiego wybrzeża zlokalizowanego na wschód od portu w Ustce. W tym celu przeanalizowano zmienność przebiegu górnej krawędzi klifu w Orzechowie w różnych skalach czasowych. Wielkość erozji określano na podstawie map archiwalnych oraz przeprowadzonych w terenie serii pomiarowych LiDAR z wykorzystaniem naziemnego skaningu laserowego. W oparciu o wielkość erozji wyznaczano uśrednione tempo erozji klifu [ $\mathrm{m} \mathrm{a}^{-1}$ ] dla każdego umownego profilu prostopadłego do brzegu. Zaprezentowana metoda umożliwia porównanie tempa postępującej erozji klifów wybrzeży Bałtyku w sposób jednolity, niezależnie od budowy geologicznej, wysokości czy ekspozycji zboczy.
\end{abstract}

Słowa kluczowe: morfodynamika, klif, erozja, teledetekcja, LiDAR

\begin{abstract}
The aim of this paper was quantitative and qualitative investigation of morphodynamics of high coast located to the east of the Ustka harbour. Therefore, the course variability of top margins of the Orzechowo Cliff became analysed at different time scales. The magnitude of erosion was obtained from archival maps and/or LiDAR field measurements using terrestrial laser scanner. Based on the magnitude of erosion, the average recession rate of the cliff $\left[\mathrm{m} \mathrm{a}^{-1}\right]$ was determined for every hypothetical profile perpendicular to the shore. The presented approach provides the possibility to compare the recession rates of cliffs of the Baltic coast in a uniform manner, regardless of geological structure, elevation, or slope exposure.
\end{abstract}

Keywords: morphodynamics, cliff, erosion, remote sensing, LiDAR

\section{Wstęp}

W skali długofalowej model mający na celu określenie reakcji wybrzeży zbudowanych z utworów słabo skonsolidowanych (Carpenter i in. 2014) na wahania poziomu morza i falowanie przeanalizowany przez Trenhaile'a (2010) wskazuje, że wzrost poziomu morza $\mathrm{w}$ największym stopniu przyspieszy recesję klifów, podczas gdy wzrost częstotliwości sztormów może odpowiadać za niewielki wzrost tempa erozji. Jednakże w odniesieniu do południowego Bałtyku, który uznawany jest za morze bezpływowe, to krótkookresowe czynniki morfogenetyczne (prędkość i kierunek wiatru, stan i poziom morza, intensywność opadów, poziom wód gruntowych) i sto- pień antropopresji kształtują wybrzeża w najbardziej zauważalny sposób, głównie poprzez oddziaływanie ekstremalnych zjawisk meteorologicznych - sztormów i długotrwałych ulewnych deszczy (Zawadzka-Kahlau 1999, Florek i in. 2008, Kostrzewski i in. 2015). Wpływają one na polską strefę brzegową, prowadząc do degradacji rozległych obszarów. W takich warunkach może dochodzić do wynoszenia znacznych ilości materiału osadowego. Naturalną reakcją wybrzeża na warunki sztormowe jest systematyczny rozwój platformy abrazyjnej oraz erozja podbrzeża, brzegu i nadbrzeża, a więc i sukcesywna recesja klifów.

Ograniczanie skutków erozji jest niezwykle istotne, zwłaszcza z punktu widzenia zachowania wy- 
brzeży morskich wraz $z$ istniejącą infrastrukturą powstałą na potrzeby lokalnych społeczności i turystyki. Zdolność przewidywania przyszłych zmian wymaga rozpoznania związków przyczynowo-skutkowych pomiędzy szeregiem aktywnych i pasywnych czynników, od których zależy tempo niszczenia brzegu. Miejscowe plany zagospodarowania przestrzennego powinny wobec tego uwzględniać lokalne tendencje rozwojowe wybrzeży $\mathrm{w}$ różnych skalach czasowych. W literaturze stosowano różne metody oceny tempa recesji klifów (Subotowicz 1982, Zawadzka-Kahlau 1999, Kramarska i in. 2011, Uścinowicz i in. 2014, Kostrzewski i in. 2015, Frydel i in. 2017). Tempo erozji klifów określano w odniesieniu do zmienności przebiegu linii brzegowej, linii podstawy klifu linii korony klifu, lub na podstawie pomiarów prowadzonych na profilach poprzecznych do brzegu. $Z$ wymienionej grupy górna krawędź klifu jest jedynym wskaźnikiem, który bez udziału człowieka nie może przyrosnąć, tj. przesunąć się w stronę morza. Wobec tego odwzorowanie przebiegu korony stanowi unikalną i jednoznaczną sygnaturę stanu klifu opisaną współrzędnymi $x, y, z$, $\mathrm{w}$ funkcji czasu $t$. Zatem wielokrotna dokumentacja chwilowego stanu fragmentu klifu na podstawie kolejnych zobrazowań (wykonanych w czasie $t_{1}, t_{2}$ itd.) umożliwia określenie wielkości i średniego tempa erozji dla danego interwału czasu $\left(t=t_{1}-t_{2}\right)$. Rozwój teledetekcji oraz zaawansowanych systemów przetwarzania danych pozwala na rozpoznanie wielkości erozji w przeszłości, tym samym umożliwiając oszacowanie tempa erozji w przyszłości poprzez ekstrapolację uzyskanych wyników.

W niniejszym opracowaniu do cyklicznych pomiarów morfologii brzegu i nadbrzeża (Rudowski 1962), a w konsekwencji określenia wielkości i tempa erozji klifu zastosowano nowoczesną metodę naziemnego skaningu laserowego. Rezultaty pomiarów LiDAR zestawiono $\mathrm{z}$ archiwalnymi materiałami kar- tograficznymi (WG UAM 2016, CODGiK). W systemie geoinformacyjnym wyznaczono na tej podstawie wielkość erozji, a następnie obliczono średnie tempo erozji w odniesieniu do przebiegu korony klifu. Termin tempo erozji stanowi odniesienie do prędkości niszczenia wybrzeży stromych, cofania się klifu i rozmiarów cofania się brzegów [ $\mathrm{m} \mathrm{a}^{-1}$ ] (Klimaszewski 1981). W efekcie dla około 2-kilometrowej długości odcinka wybrzeża w rejonie Orzechowa rozpoznano występowanie trendu malejącego ku wschodowi we wszystkich zbadanych skalach czasowych. Zgodnie $z$ danymi literaturowymi zwrot i kierunek wektora opisującego wypadkowy transport wzdłużbrzegowy rumowiska skierowany jest ku wschodowi (Dobrzyński 1998, Zawadzka-Kahlau 1999), co znajduje również potwierdzenie $\mathrm{w}$ zdjęciach lotniczych i zobrazowaniach satelitarnych. Wyznaczony rozkład wielkości erozji i tempa recesji klifu obrazuje zakres oddziaływań związany ze stopniowym wygaszaniem zasięgu wpływu falochronów portu w Ustce, w większym stopniu niż różnic związanych z budową geologiczną, wysokością i ekspozycją klifu. Przedstawione badania stanowią rozwinięcie zagadnienia wstępnie omówionego przez Frydel i in. (2017).

\section{Obszar badań}

Rejon badań zlokalizowany jest na środkowym wybrzeżu Polski, na wschód od Ustki (ryc. 1) w województwie pomorskim. Obszar ten położony jest na Wybrzeżu Słowińskim w obrębie Pobrzeża Koszalińskiego (Kondracki 2009). Obejmuje równinę zastoiskową przykrytą osadami eolicznymi opadającą stromymi zboczami klifów w kierunku Morza Bałtyckiego. Wysokość klifów wynosi tu od 5 do $20 \mathrm{~m}$ (Zachowicz, Dobracki 2003). W środkowej części rejonu badań (około 229,3 km wybrzeża) w okolicy

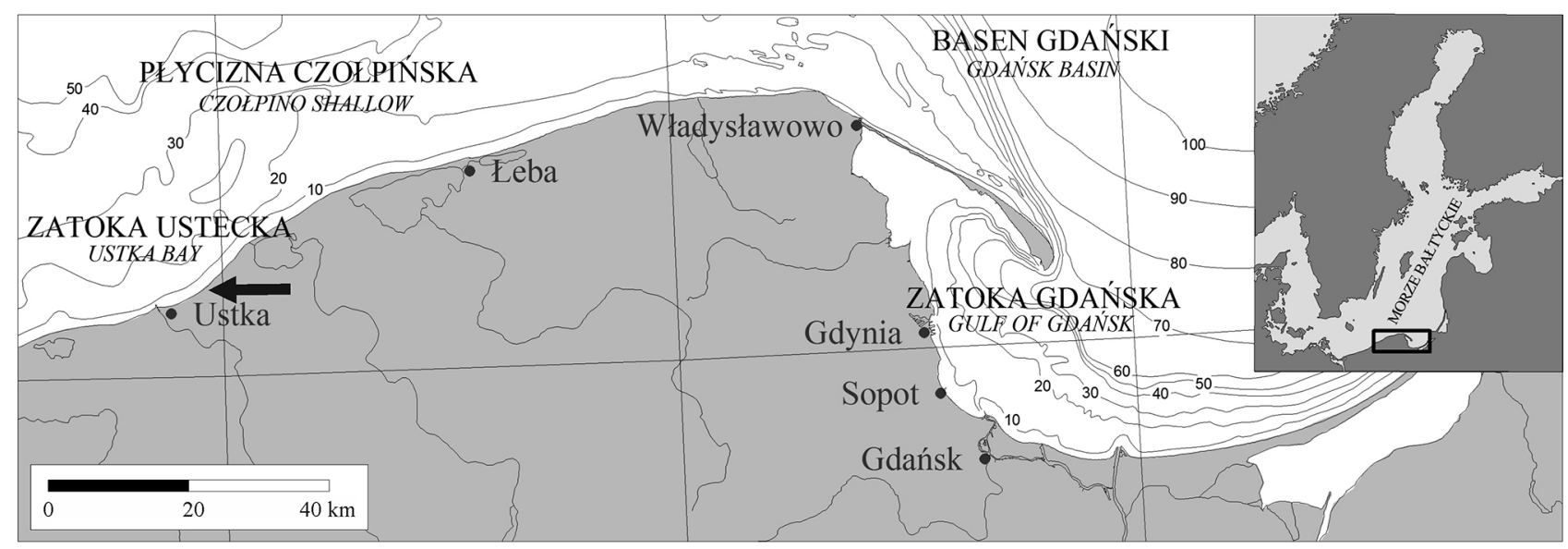

Ryc. 1. Fragment polskiego wybrzeża z orientacyjną lokalizacją rejonu badań

Fig. 1. Part of the Polish coast with location of the research area 


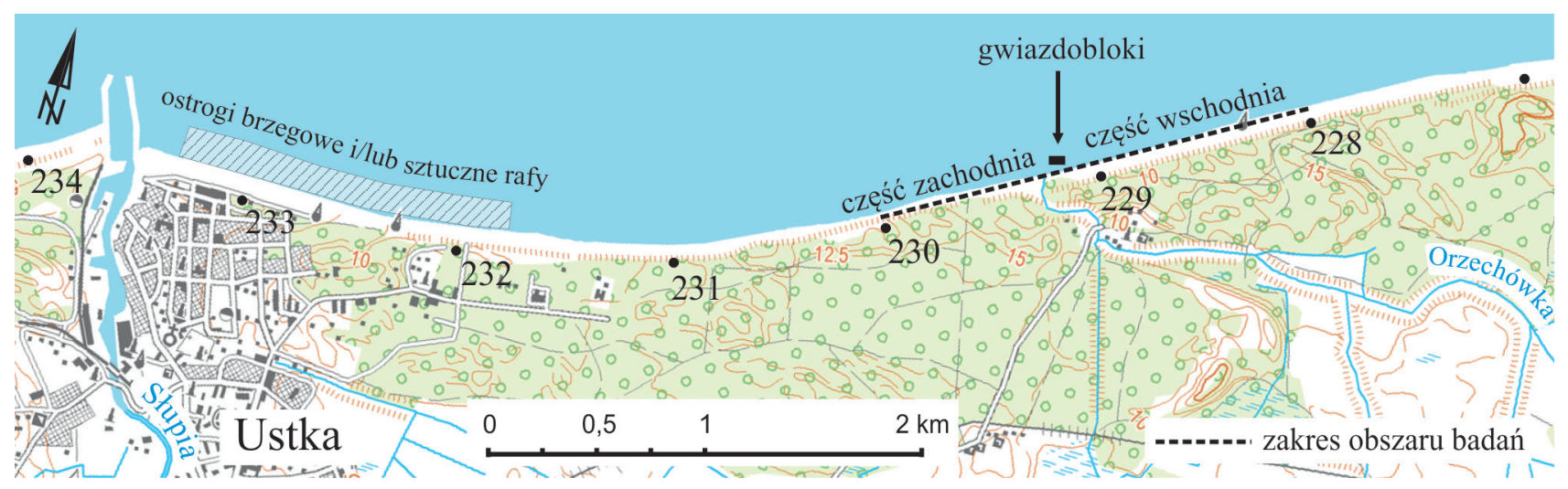

Ryc. 2. Obszar badań na tle mapy topograficznej z zaznaczonymi umocnieniami brzegu

Fig. 2. Research area on the background of topographic map with marked coastal defence systems

Orzechowa uchodzi do Zatoki Usteckiej rzeka Orzechówka, która w sposób umowny dzieli obszar badań na część zachodnią (W) i wschodnią (E) (ryc. 2).

Pod względem zagospodarowania i użytkowania terenu jest to obszar o funkcji rekreacyjno-wypoczynkowej. Bezpośrednie zaplecze klifu porośnięte jest rzadkim lasem sosnowym. Cały rejon badań zlokalizowany jest w obrębie Obszaru Chronionego Krajobrazu Pas Pobrzeża na wschód od Ustki, natomiast część na wschód od ujścia Orzechówki należy ponadto do obszaru Natura 2000 Klify Poddębskie PLH220100. Szczegółowym obserwacjom został poddany fragment aktywnego klifu o długości około $2 \mathrm{~km}$ położony między 228 i $230 \mathrm{~km}$ brzegu według Urzędu Morskiego (ryc. 3).

W rejonie Orzechowa i Ustki bezpośrednim podłożem osadów plejstoceńskich są mioceńskie piaski i mułki $z$ węglem brunatnym (Uniejewska, Nosek 1986). Widoczny w obrębie klifu strop pokrywy glin zwałowych nie przekracza wysokości 5 m n.p.m. (Zachowicz, Dobracki 2003). Powyżej występują osady zastoiskowe i piaszczyste osady wodnolodowcowe, piaski w wydmach (ryc. 4), a miejscami torfy o miąż- szości $<2$ m wraz z towarzyszącymi im wysiękami (ryc. 5). W rejonie badań osady zalegające w odsłonięciach są niekiedy silnie zaburzone glacitektonicznie oraz synsedymentacyjnie (Jurys i in. 2006). Intensywnie erodowane odcinki klifu aktywnego rozcinają występujące powszechnie na tym obszarze miąższe pokrywy piasków eolicznych (Uniejewska, Nosek 1986). Erozja wybrzeża klifowego w tym rejonie ma związek z obecnością falochronu portu usteckiego (Florek i in. 2013), który powoduje przecięcie głównego potoku rumowiska przemieszczanego z zachodu na wschód (Dobrzyński 1998, Zawadzka-Kahlau 1999). W zależności od budowy geologicznej klifu występują tu różne rodzaje procesów stokowych: osuwiska, obrywy, zsuwy i osypiska (Subotowicz 1982). Powstawanie osuwisk warunkowane jest m.in. występowaniem wypływów wody gruntowej ze zboczy (Florek i in. 2013).

Największe zniszczenia abrazyjne zachodzą, kiedy brzeg nie jest chroniony pokrywą lodową (Cyberski 2011) przed silnymi sztormami powstajacymi przy wietrze wiejącym z sektora N-NE (ZawadzkaKahlau 1999).

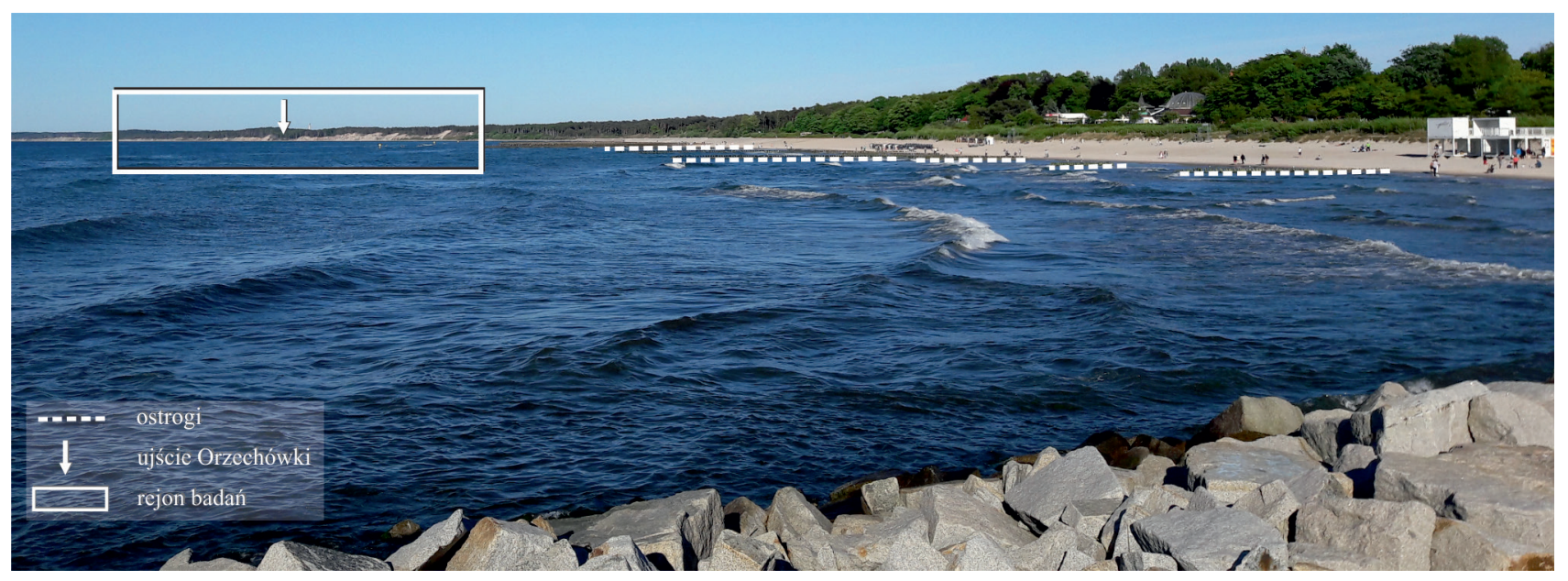

Ryc. 3. Widok na Zatokę Ustecką z falochronu portowego w Ustce

Fig. 3. View of the Ustka Bay from the Ustka harbour breakwater 


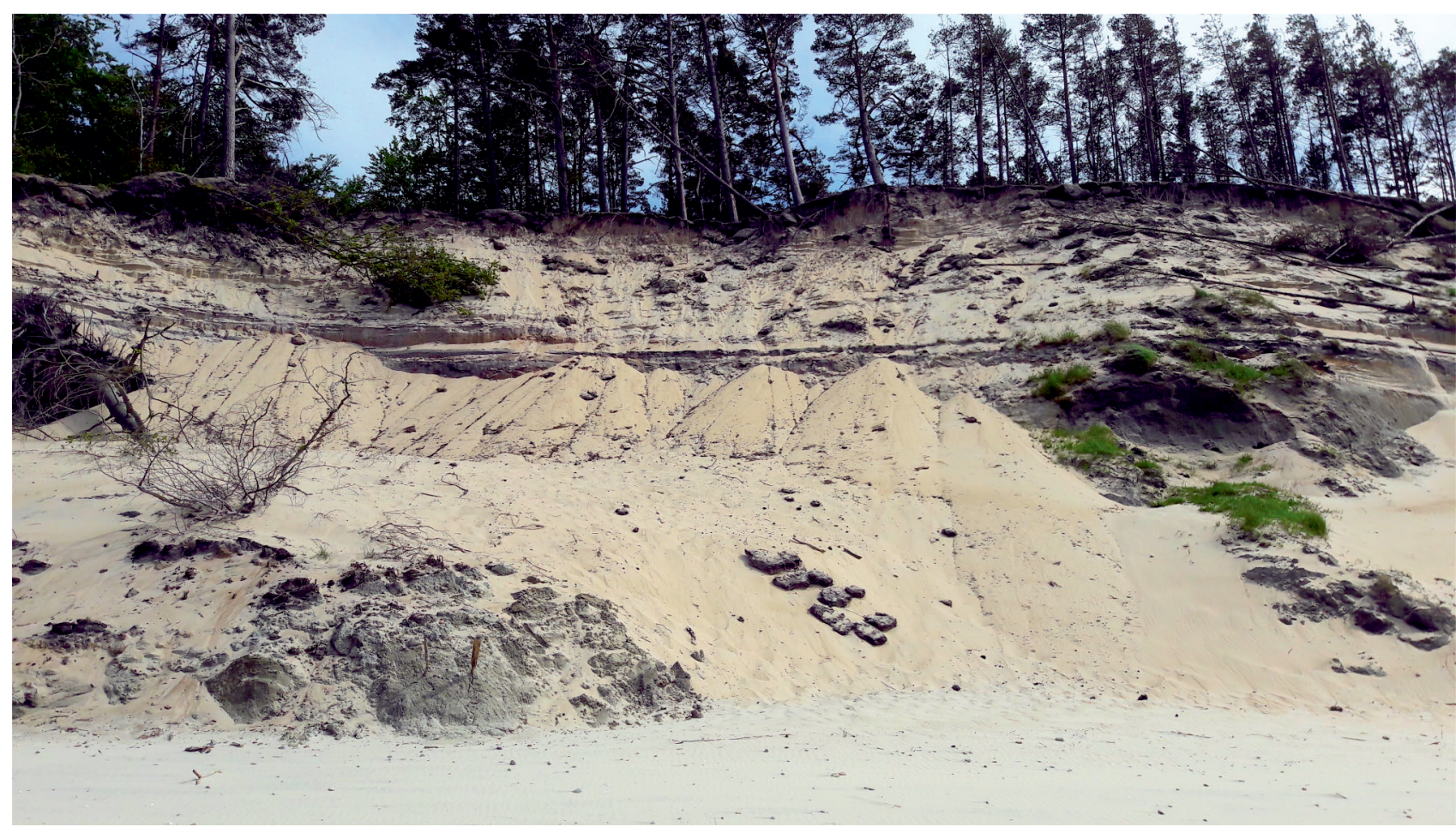

Ryc. 4. Stożki osypiskowe w rejonie 229,70 km UM (fot. J. Frydel, 2016)

Fig. 4. Talus cones near 229.7 chainage km (photo J. Frydel, 2016)

Na podstawie budowy geologicznej (Zachowicz, Dobracki 2003, Jurys i in. 2006), zgodnie z podziałem Bohdziewicza (1963), występujące na badanym obszarze typy wybrzeża od około 230,2-228,75 km UM (na wschód od portu w Ustce) można sklasyfikować jako klifowe, z osłoną wydmową nadkrawędziową, z wyłączeniem niskiego obszaru ujścia rzeki Orzechówki i dalej na wschód od 228,75 km UM, gdzie klify ustępują miejsca wybrzeżom wydmowym średniej wysokości i niskim, wykraczającym aż poza zakres analizowanego obszaru.

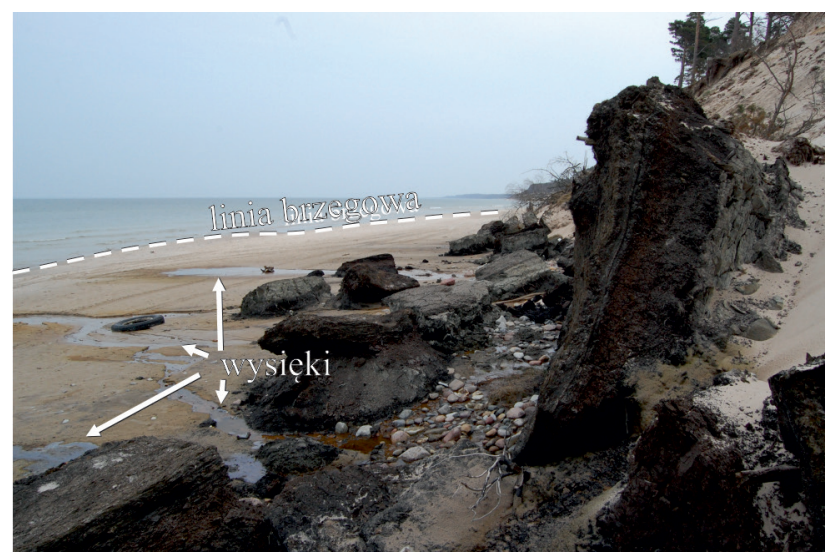

Ryc. 5. Pokłady torfów i gytii na 230,3 km i towarzyszące im wysięki (fot. J. Frydel, 2016)

Fig. 5. Layer of peat and gyttja near 230.3 chainage km accompanied by groundwater seepages (photo J. Frydel, 2016)
Pod względem występowania systemów ochrony brzegu badany teren można uznać za zbliżony do naturalnego. Jednak brzeg $\mathrm{w}$ tym rejonie podlega różnym formom ochrony od ponad 90 lat (Florek, Florek 1995). Do wyjątków można zaliczyć odcinek o długości $30 \mathrm{~m}$ w sąsiedztwie ujścia Orzechówki, gdzie wykonano narzut z gwiazdobloków. Natomiast na wschód od wejścia do portu w Ustce (tj. ujścia rzeki Słupi) istnieje system ponad trzydziestu ostróg brzegowych zachowanych w różnym stopniu (ryc. 2), o długościach od $10 \mathrm{~m}$ do ponad $90 \mathrm{~m}$ (przeważnie 30-40 m). W 2015 r. w odległości około $200 \mathrm{~m}$ od brzegu na odcinku $850 \mathrm{~m}$ posadowiono również sztuczne rafy.

\section{Materiały i metody}

Wielkość erozji klifu w Orzechowie wyznaczono na podstawie porównania przebiegu korony klifu $z$ lat 1889, 2000, 2010, 2011, 2015 i 2016. W tym celu wykorzystano materiały kartograficzne i teledetekcyjne. Przebieg linii korony klifu z roku 1889 określono na podstawie niemieckiej mapy topograficznej Messtischblatt $\mathrm{w}$ skali 1:25 000. Wykorzystano dwa arkusze: Neu-Strand (Poddąbie), nr 214 (1367) oraz Stolpmünde, nr 265 (1467) (WG UAM 2016), którym nadano georeferencję $\mathrm{w}$ oprogramowaniu geoinformacyjnym w oparciu o współrzędne geograficzne narożników map. Dane z 2000 r. pochodzą z mapy topograficz- 


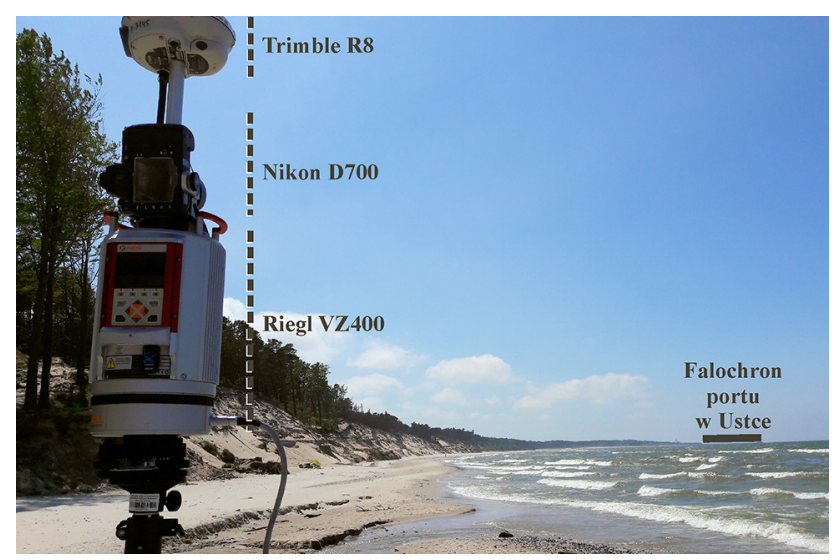

Ryc. 6. Składowe systemu naziemnego skaningu laserowego (fot. J. Frydel, 2016)

Fig. 6. Components of the terrestrial laser scanning system (photo J. Frydel, 2016)

nej w skali 1:10 000 pozyskanej z zasobów CODGiK (N-33-58-B-B-3). Obydwu zeskanowanych i zgeoreferencjonowanych arkuszy użyto jako podkładów do wektoryzacji linii wyznaczającej przebieg korony klifu. Pozostałe górne krawędzie klifu z lat 2010-2016 określono na podstawie cyfrowych modeli wysokościowych (CMW) będących rezultatem pomiarów LiDAR przeprowadzonych przez autorów. Pomiary wykonano techniką naziemnego skaningu laserowego TLS (ang. Terrestrial Laser Scanning), za pomoca skanera Riegl VZ-400. Naziemny skaner laserowy (ryc. 6) jest urządzeniem umożliwiającym pomiar quasi-ciągłej powierzchni reprezentującej obiekty pozostające $\mathrm{w}$ sąsiedztwie skanera.

W dużym uproszczeniu obrazowanie powierzchni (ryc. 7) następuje w wyniku emisji spójnych wiązek promieniowania elektromagnetycznego przez urządzenie, ich odbicia od przeszkody i rejestracji przez receptory (fotodiody) zlokalizowane $\mathrm{w}$ sąsiedztwie centrum optycznego skanera (Wężyk 2006, Petrie, Toth 2009). W oparciu o znaną wartość prędkości światła w danym ośrodku i precyzyjne określenie kąta emisji, jak również pomiar czasu pomiędzy emisją a rejestracją, wyznaczona zostaje odległość do zmierzonego obiektu (punktu). Wynikiem skanowania jest zbiór punktów, tzw. chmura punktów o trzech współrzędnych, mająca odniesienie przestrzenne do środka optycznego skanera. Użyty skaner umożliwił pomiar nawet $125000 \mathrm{pkt} \mathrm{s}^{-1}$, podczas gdy maksymalna gęstość pierwotnej chmury punktów opisującej powierzchnię klifu dochodziła do 2500 pkt $\mathrm{m}^{-2}$ (dla kąta emisji fotonów równego $0,04^{\circ}$ ). Aby umożliwić najpełniejsze odwzorowanie powierzchni badanego odcinka klifu, wymagane było wykonanie

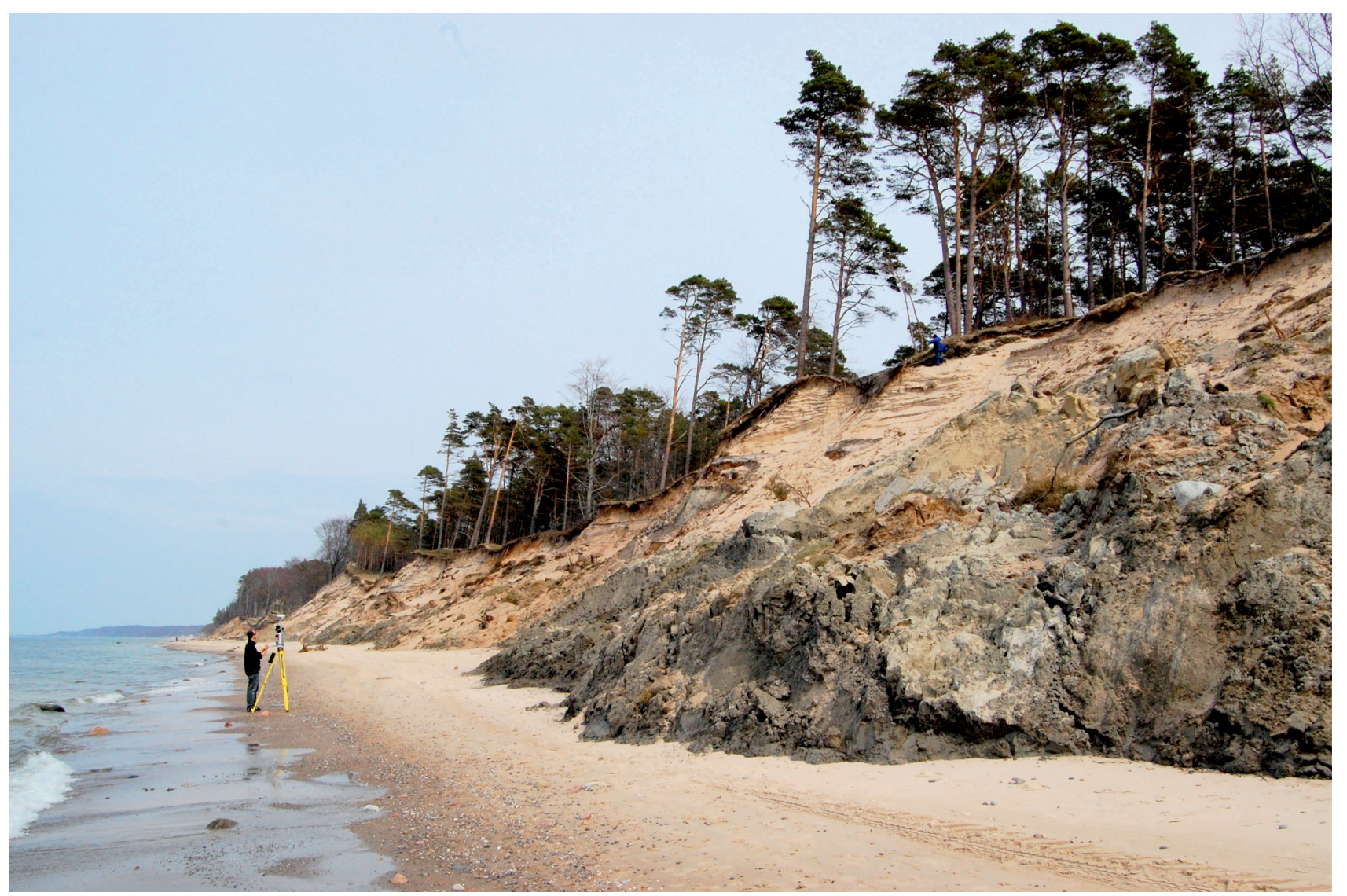

Ryc. 7. Osuwisko przy 229,65 km UM (fot. W. Jegliński, 2010)

Fig. 7. Landslide at 229.65 chainage km (photo W. Jegliński, 2010) 
Tabela 1. Parametry definiujące pozycje dwóch przykładowych pozycji skanera

Table 1. Parameters defining location of two example scan positions

\begin{tabular}{|c|c|c|c|c|c|c|c|c|c|}
\hline \multirow{2}{*}{ Nazwa punktu } & \multirow{2}{*}{ Data i godzina } & Prec $\mathrm{H}$ & Prec V & PDOP & RMS & Sat & $\mathrm{X}$ & $\mathrm{Y}$ & Z \\
\hline & & \multicolumn{2}{|c|}{$[\mathrm{m}]$} & {$[-]$} & {$[\mathrm{mm}]$} & \multicolumn{4}{|c|}{$[-]$} \\
\hline 5orz_14a & $2016-06-08$ 15:43 & 0,009 & 0,013 & 1,8 & 18 & 7 & 6052379,977 & 6429449,412 & 3,113 \\
\hline 5orz_14b & 2016-06-08 15:44 & 0,009 & 0,012 & 1,8 & 15 & 7 & 6052379,982 & 6429449,412 & 3,116 \\
\hline 5orz_14c & 2016-06-08 15:44 & 0,009 & 0,012 & 1,8 & 16 & 7 & 6052379,978 & 6429449,410 & 3,124 \\
\hline 5orz_15a & 2016-06-08 15:49 & 0,009 & 0,013 & 1,7 & 20 & 8 & 6052366,905 & 6429407,562 & 2,911 \\
\hline 5orz_15b & $2016-06-08$ 15:50 & 0,008 & 0,012 & 1,7 & 15 & 8 & 6052366,898 & 6429407,559 & 2,916 \\
\hline $5 o r z \_15 c$ & $2016-06-08$ 15:50 & 0,008 & 0,011 & 1,7 & 14 & 8 & 6052366,901 & 6429407,564 & 2,914 \\
\hline
\end{tabular}

skanowania nawet z 60 kolejnych stanowisk. Przeniesienie każdej chmury punktów z lokalnego układu współrzędnych skanera do układu PL-2000 realizowano dzięki nawigacji satelitarnej zapewnianej przez urządzenie Trimble R8 GNSS współpracujące ze skanerem. Odbiornik Trimble R8 do wyznaczenia pozycji korzystał zarówno z satelitów amerykańskiej sieci GPS, jak i rosyjskiej GLONASS. Poprawki różnicowe pozycji z systemu Aktywnej Sieci Geodezyjnej EUPOS były uzyskiwane na bieżąco i umożliwiły wyznaczenie współrzędnych $X, Y, Z$ stanowisk skanera $z$ dokładnością maksymalnie kilku centymetrów (tab. 1). Stanowiska skanera (współrzędne jego centrum optycznego) każdorazowo definiowały centrum chmury punktów podlegającej procesowi rejestracji w układzie PL-2000. Współrzędne $X, Y, Z$ dla poszczególnych pozycji skanowania uzyskiwano w wyniku uśrednienia wartości z trzech pomiarów RTN (ang. Real Time Network). W przypadku gdy zmierzony punkt opisany był wysoką wartością precyzji poziomej (Prec $H[\mathrm{~m}]$ ), precyzji pionowej (Prec $V[\mathrm{~m}]$ ), rozmycia precyzji wyznaczenia pozycji (ang. Position Dilution of Precision - PDOP), błędu standardowego RMS (ang. Root Mean Square), lub opisany przez niską ilość satelitów (Sat), zostawał wykluczony z kalkulacji. Należy mieć na uwadze, że przed scaleniem położenie punktów dla poszczególnych chmur było wyrównywane za pomocą algorytmu MSA (ang. Multi Station Adjustment) aż do uzyskania wyniku scharakteryzowanego konfiguracją wartości poprawek najbardziej zbliżoną do rozkładu Gaussa (rozkładu normalnego), a w konsekwencji opisanego możliwie niską wartością RMS (ryc. 8). Istotne jest rozróżnienie pomiędzy opisanymi typami błędów RMS. Pierwsza wartość (tab. 1) określa błąd wyznaczenia położenia skanera dla poszczególnych pomiarów RTN, druga natomiast (ryc. 8) definiuje średni błąd dopasowania wszystkich punktów w obrębie jednej kampanii pomiarowej.

W związku z powyższym przy łączeniu chmur punktów $z$ różnych stanowisk mogły następować minimalne przesunięcia uzyskanych współrzędnych $\mathrm{w}$ oparciu o wspólne pokrycie tego samego obszaru przez różne chmury. Spójność wpasowania chmur punktów reprezentujących powierzchnię klifu w Orzechowie dla każdej z kolejnych pięciu serii pomiarowych opisywała wartość odchylenia standardowego (RMS) nie gorsza niż $25 \mathrm{~mm}$. Na rycinie 9 przedstawiono reprezentatywną dla udokumentowanego obszaru próbkę danych TLS bezpośrednio przed połączeniem w jeden zbiór. Stwierdzono, że zewidencjonowane chmury punktów $\mathrm{w}$ satysfakcjonujący sposób opisują badane powierzchnie. Dwukrotnie niższe wartości różnic $(<5 \mathrm{~cm})$ nie mają istotnego

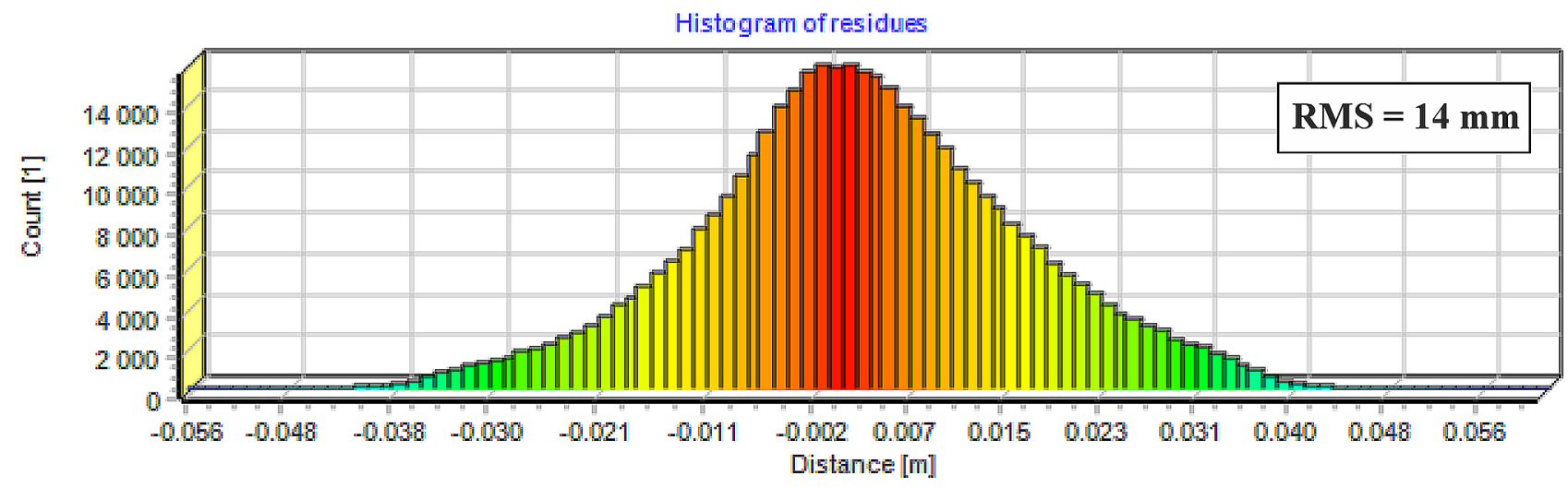

Ryc. 8. Przykładowy histogram o charakterze rozkładu normalnego dla 60 chmur punktów piątej serii pomiarowej TLS w 2016 r., błąd standardowy (RMS) $=14 \mathrm{~mm}$

Fig. 8. Example of a normal distribution histogram prepared for 60 point clouds of the 5 th measurement campaign in 2016 , error $(\mathrm{RMS})=14 \mathrm{~mm}$ 


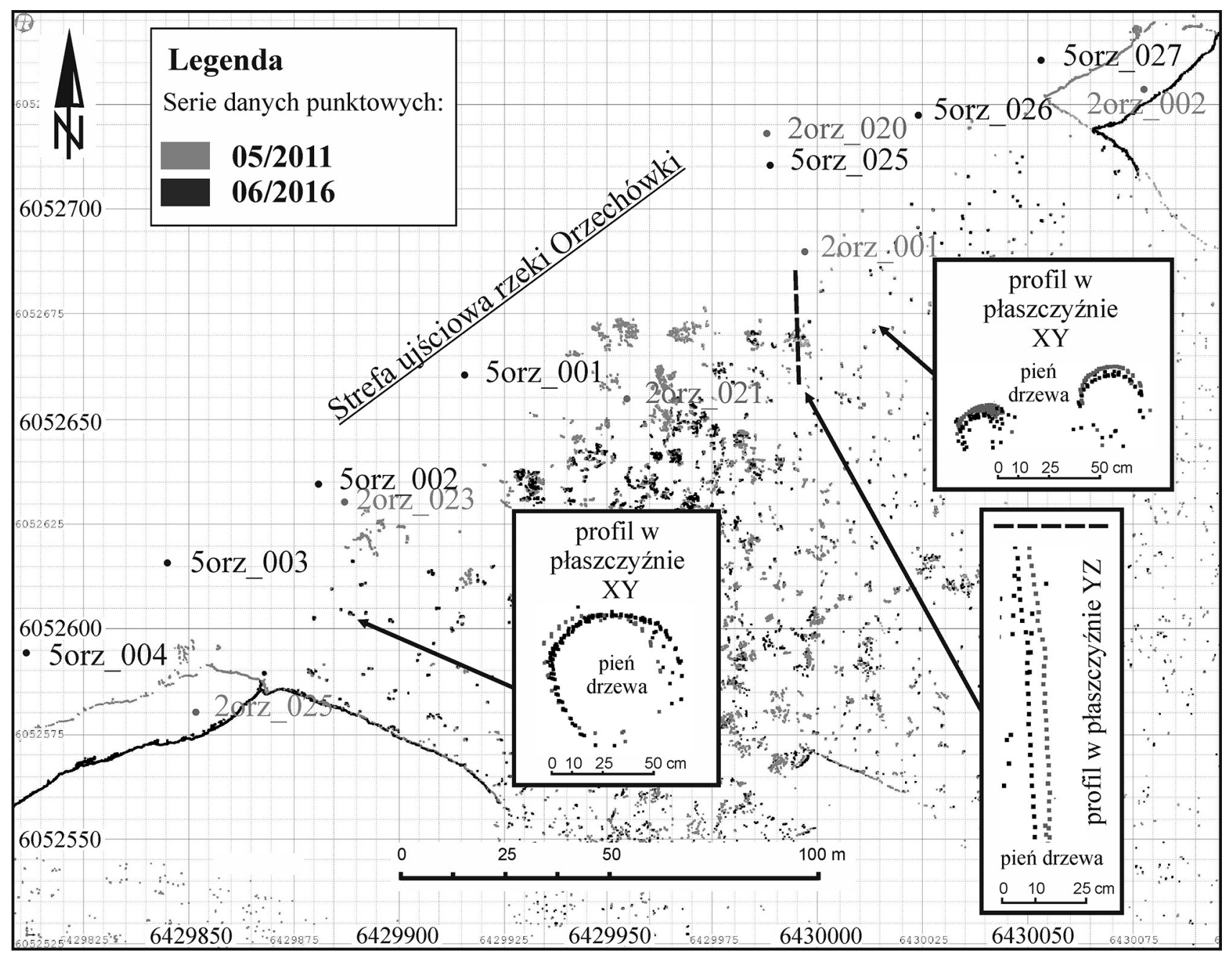

Ryc. 9. Wizualizacja rozbieżności między seriami danych TLS dla lat 2011 i 2016 na rzędnej 12 m n.p.m. A i B - w płaszczyźnie poziomej (XY), C - w płaszczyźnie pionowej YZ

Fig. 9. Visualisation of differences between TLS data series for 2011 and 2016 at elevation of $12 \mathrm{~m}$ a.s.l. $\mathrm{A}$ and $\mathrm{B}$ - horizontal plane XY, C - vertical plane YZ

wpływu na końcową dokładność odwzorowania powierzchni za pomocą powstałego na ich podstawie CMW o rozdzielczości $10 \mathrm{~cm}\left(100 \mathrm{pkt} \mathrm{m}^{-2}\right)$.

Bezpośrednie wyniki skaningu w postaci chmur punktów opracowano w programie RiSCAN PRO. Po złączeniu chmur należących do jednej serii pomiarowej odfiltrowano te punkty, które odpowiadały roślinności i innym obiektom nienależącym do podłoża. Następnie zbiór punktów reprezentujących powierzchnię klifu, plaży i zaplecza klifu poddano triangulacji, tj. konwersji do siatki TIN (ang. Triangular Irregular Network) zbudowanej z nieregularnej sieci trójkątów reprezentującej numeryczny model terenu (NMT). Wynikowe NMT powstały poprzez resampling chmur punktów do siatki o regularnym interwale $10 \mathrm{~cm}\left(\mathrm{tj} .100 \mathrm{pkt} \mathrm{m}^{-2}\right)$. Przebiegi linii korony klifu wyznaczono w trójwymiarowym środowisku RiSCAN PRO. Analizy wykonano dla kolejnych serii pomiarowych: odcinka zachodniego w latach 2010,
2011, 2015 i 2016; odcinka wschodniego w latach 2011, 2015 i 2016.

Dla badanego obszaru określano również rzeczywiste (3D) ubytki skał budujących brzeg i nadbrzeże $\mathrm{w}\left[\mathrm{m}^{3}\right]$. Za dolną granicę analiz przyjęto linię brzegową, rozumianą jako linię przebiegu izohipsy $0 \mathrm{~m}$ (w odniesieniu do wysokości geoidy dla województwa pomorskiego). Górną granicę analiz stanowiła linia przebiegu korony klifu w roku 2016. Rzeczywista wielkość erozji brzegu i nadbrzeża, która nastąpiła w ciągu pięciu lat (2011-2016), wyznaczono dla przystających zakresów NMT za pomocą funkcji cut and fill. Następnie w oparciu o zwektoryzowane linie korony klifu dla wszystkich serii danych w programie ArcMap (ESRI) obliczano powierzchnię ubytku brzegu klifowego (2D) $\mathrm{w} \mathrm{m}^{2}$. Na tej podstawie określano średnie tempo erozji dla wszystkich umownych profili prostopadłych do brzegu dla kolejnych okresów [m a $\left.{ }^{-1}\right]$. 
Wielkość erozji (ubytek wybrzeża w 2D) jest rozumiana jako średnia odległość pomiędzy starszym a młodszym położeniem korony klifu. Natomiast średnie tempo erozji $(R)$ obliczano jako iloraz pola powierzchni $A\left(t_{1} t_{2}\right)$ ograniczonego skrajnym przebiegiem korony klifu (w czasie $t_{1}$ i $t_{2}$ ) rzutowanym na płaszczyznę XY oraz iloczynu długości linii bazowej (B) i liczby określającej długość badanego okresu $w$ latach $(t)$ zgodnie $z$ równaniem:

$$
\mathrm{R}=A\left(t_{1} t_{2}\right) / t B\left[\mathrm{~m} \mathrm{a}^{-1}\right]
$$

$R$ - średnie tempo erozji klifu [ $\mathrm{m} \mathrm{a}^{-1}$,

$A\left(t_{1} t_{2}\right)$ - wielkość erozji w czasie pomiędzy $t_{1}$ i $t_{2}\left[\mathrm{~m}^{2}\right]$, $t_{1}-$ znacznik czasu dla pierwszej serii danych,

$t_{2}-$ znacznik czasu dla drugiej serii danych,

$t$-ilość lat (interwał) pomiędzy $t_{1} i t_{2}$ [a],

$B$ - długość linii bazowej [m].

Określenie wielkości i tempa erozji w klasycznym ujęciu może bazować na analizie zmienności przebiegu ograniczonej ilości profili (n-profili) prostopadłych do brzegu (Subotowicz 1982, Florek i in. 2008, Łęczyński, Kubowicz-Grajewska 2013). Natomiast podejście przedstawione $\mathrm{w}$ powyższym opracowaniu umożliwia wyznaczenie średniego tempa erozji dla wszystkich prostopadłych do brzegu (umownych) profili morfologicznych w obrębie analizowanego odcinka wybrzeża klifowego. Intensywność niszczenia klifów polskiej strefy brzegowej określali za pomocą wskaźnika w postaci średniego tempa erozji dotychczas Kolander i in. (2013), Kostrzewski i in. (2015) i Frydel i in. (2017), jednak bez podania szczegółowej metody obliczeń.

\section{Wyniki}

Współczesne tempo erozji klifu w Orzechowie należy uznać za bardzo wysokie (ryc. 10, tab. 2). W części zachodniej średnie tempo erozji było równe $2,1 \mathrm{~m} \mathrm{a}^{-1}$ w latach 2011-2016, podczas gdy wschodnia część bardziej oddalona od portu podlegała dwukrotnie niższej erozji, tj. 1,1 $\mathrm{m} \mathrm{a}^{-1}$. Dla pierwszej dekady XXI w. obliczone tempo recesji korony klifu wynosiło odpowiednio 4,8 $\mathrm{m} \mathrm{a}^{-1}$ dla części $\mathrm{W}$ i było około dwukrotnie niższe dla części E, tj. 2,8 $\mathrm{m} \mathrm{a}^{-1}$. Podobny trend zaobserwowano $\mathrm{w}$ ujęciu stuletnim dla lat 1889-2000. Niszczenie klifów następowało w tempie $1,5 \mathrm{~m} \mathrm{a}^{-1}(\mathrm{~W})$ i $0,6 \mathrm{~m} \mathrm{a}^{-1}$ (E). Dokładność wykorzystanych materiałów kartograficznych jest jednak zdecydowanie niższa niż wyników przetwarzania da-

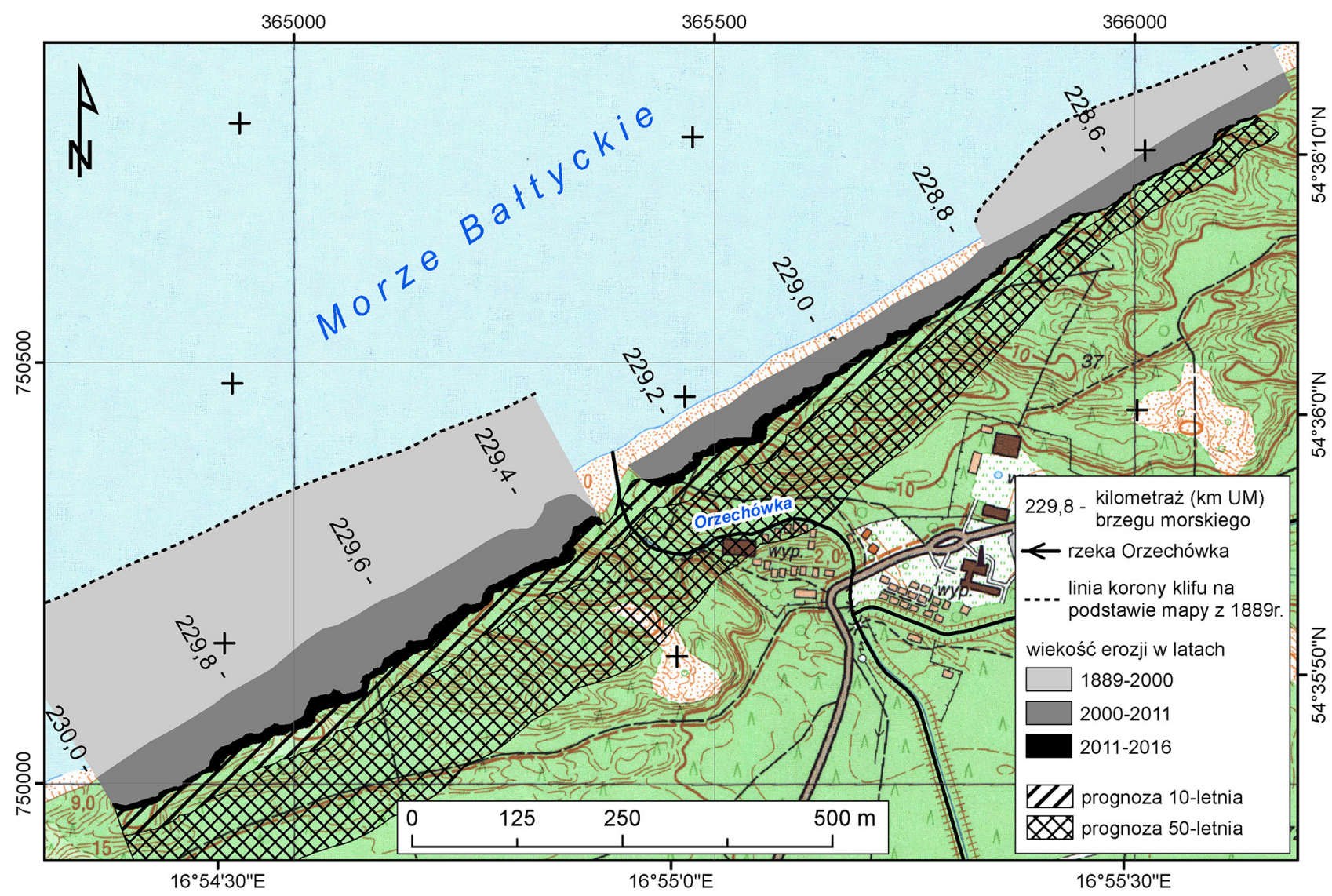

Ryc. 10. Wielkość erozji klifu w Orzechowie na tle mapy topograficznej

Fig. 10. Erosion of the Orzechowo Cliff against a topographic map 
Tabela 2. Wielkość i tempo erozji klifu w Orzechowie dla badanych okresów

Table 2. Erosion rate of the Orzechowo Cliff over a studied time period

\begin{tabular}{cccccc}
\hline Część zachodnia (W) & $\begin{array}{c}\text { Wielkość erozji } \\
{\left[\mathrm{m}^{2} \mathrm{~m}^{-1}\right]}\end{array}$ & $\begin{array}{c}\text { Średnie tempo } \\
\text { erozji }\left[\mathrm{m} \mathrm{a}^{-1}\right]\end{array}$ & Część wschodnia (E) & $\begin{array}{c}\text { Wielkość erozji } \\
{\left[\mathrm{m}^{2} \mathrm{~m}^{-1}\right]}\end{array}$ & $\begin{array}{c}\text { Średnie tempo } \\
\text { erozji }\left[\mathrm{m} \mathrm{a}^{-1}\right]\end{array}$ \\
\hline $1889-2000$ & 169,9 & 1,5 & $1889-2000$ & 61,9 & 0,6 \\
$2000-2011$ & 53,2 & 4,8 & $2000-2011$ & 30,8 & 2,8 \\
$2011-2016$ & 10,5 & 2,1 & $2011-2016$ & 5,7 & 1,1 \\
\hline
\end{tabular}

NE

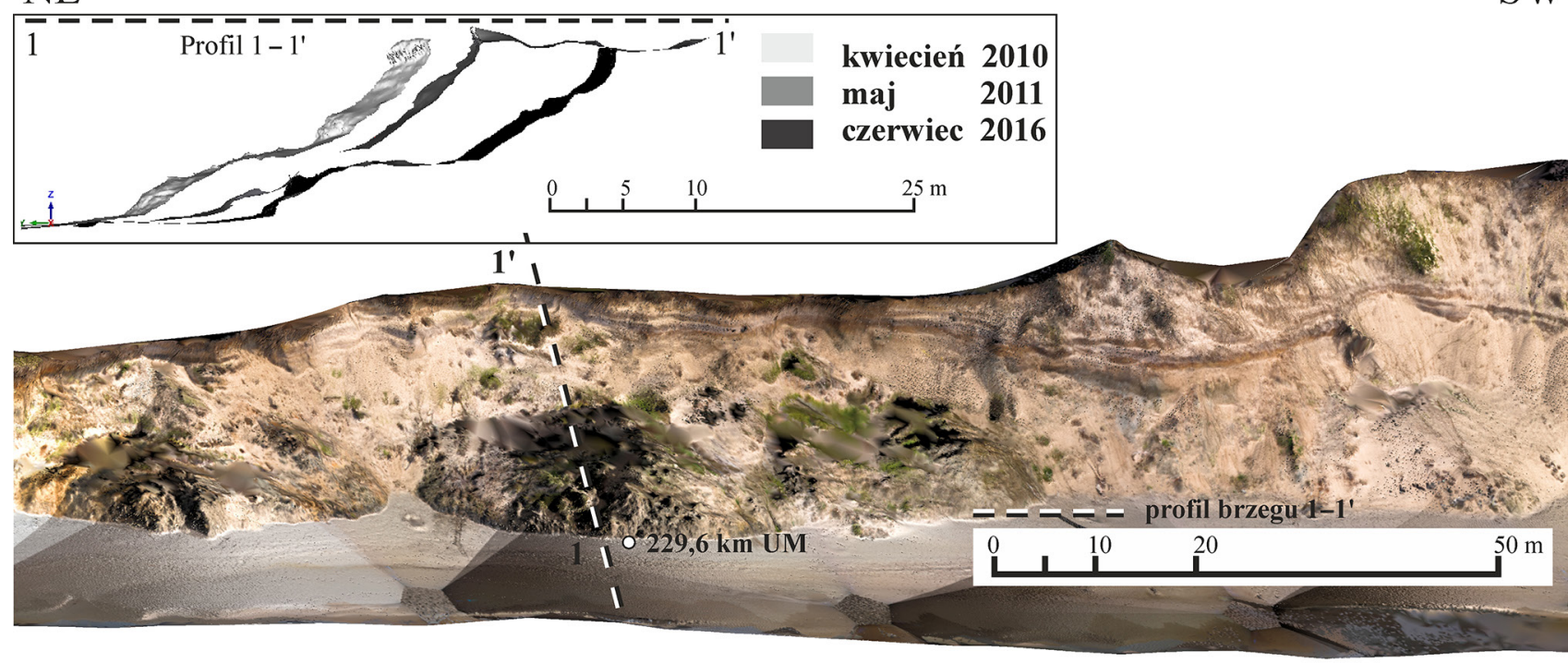

Ryc. 11. Osuwiska w zachodniej części klifu w Orzechowie w rejonie 229,6 km UM. W ramce przedstawiono profile klifu o przebiegu prostopadłym do brzegu

Fig. 11. Landslides in the western part of the Orzechowo Cliff near 229.6 chainage km. The insert depicts cliff profiles perpendicular to the coast

nych LiDAR. W związku z tym tempo erozji klifów przed 2010 r. należy traktować jako orientacyjne.

Opisana powyżej tendencja (ryc. 10, tab. 2) pokazuje malejącą ku wschodowi wielkość i tempo erozji dla drugiego (2D) i pierwszego wymiaru (1D). Trend jest również widoczny w trzecim wymiarze (3D) dla ostatniego pięciolecia 2011-2016. W części zachodniej deficyt materiału wyniósł $93170 \mathrm{~m}^{3}$, a średnie rzeczywiste tempo erozji $25,7 \mathrm{~m}^{3} \mathrm{~m}^{-1} \mathrm{a}^{-1}$. Dla odcinka położonego na wschód od rzeki Orzechówki było to $56110 \mathrm{~m}^{3}$ ze średnim tempem erozji równym $10,8 \mathrm{~m}^{3} \mathrm{~m}^{-1} \mathrm{a}^{-1}$.

$\mathrm{Na}$ badanym obszarze zróżnicowana budowa geologiczna klifu warunkuje jego podatność na degradację. W zależności od widocznych w profilu klifu wydzieleń udokumentowano współwystępujące oraz występujące cyklicznie w bliskim sąsiedztwie ruchy masowe w postaci osuwisk, osypisk i zsuwów. Osuwiska występują zwłaszcza od 229,50 do 229,75 km UM (ryc. 11). Na niewielkim obszarze sąsiadują ze

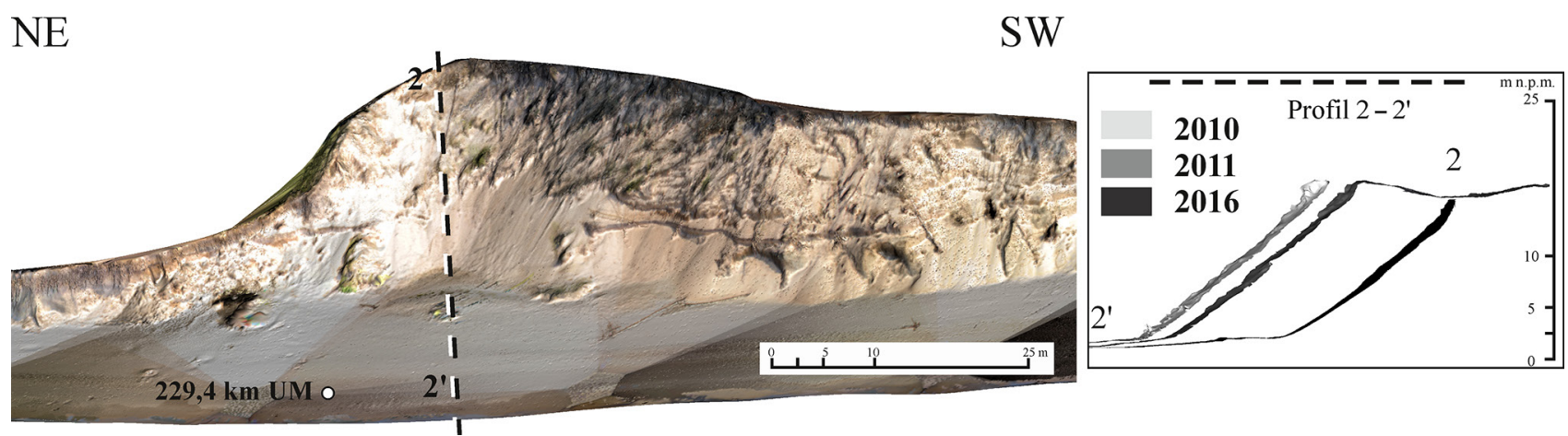

Ryc. 12. Osypiska w sąsiedztwie ujścia rzeki Orzechówki. W ramce przedstawiono profile klifu o przebiegu prostopadłym do brzegu

Fig. 12. Talus cones near the outlet of Orzechówka River. The insert depicts cliff profiles perpendicular to the coast 
stożkami osypiskowymi uformowanymi poniżej wyraźnie widocznego poziomu gleb kopalnych i torfów. Miąższość koluwiów pokazanych na rycinie 11 osuwisk jest niewielka - nie przekracza $4 \mathrm{~m}$, a strop koluwium - rzędnej 6 m n.p.m. Profil morfologiczny przeprowadzony prostopadle do brzegu $\mathrm{w}$ rejonie 229,6 km UM wskazuje, że osuwiska występują cykliczne. Na profilu z roku 2010 widoczne jest wyraźne czoło koluwium, które w kolejnym roku uległo erozji (profil nachylony jednostajnie $\mathrm{w}$ stronę morza). W 2016 r. powstało w tym miejscu następne osuwisko wykształcone $\mathrm{w}$ strefie występowania serii ilastych i mułkowych. Widoczne w koluwium osady drobnodyspersyjne zostały szczególowo rozpoznane (Jurys i in. 2006), a ich występowanie zaznaczono na litologicznym profilu wzdłużbrzegowym.

W rejonie badań na niewielkich odcinkach brzegu istnieje znacząca lokalna zmienność litologiczna osadów rozpoznanych makroskopowo w trakcie prac terenowych, która skutkuje występowaniem zróżnicowanych typów ruchów masowych. Przykładowy profil osypiska przedstawiono na rycinie 12 . W obrębie zbocza na wysokości 228,65 km UM zidentyfikowano również warstwę osadów posztormowych o miąższości około $30 \mathrm{~cm}$ zawierających minerały ciężkie z przewagą granatów.

Kąt zbocza zmierzony dla profilu 2-2' wynosi $39^{\circ}$. Wiłun (2007) określa, że powyższa wartość odpowiada górnej granicy kąta tarcia wewnętrznego dla zagęszczonych piasków grubo-i średnioziarnistych. Makroskopowo oznaczono jednak piaski drobnoziarniste, co odpowiada wynikom opisanym przez Jurysa $i$ in. (2006).

Istotny wpływ na niższe tempo niszczenia brzegu w skrajnie wschodniej części badanego obszaru ma sposób wykształcenia profilu plaży. Rzędna podstawy klifu/wydmy w części wschodniej przewyższa nawet o metr wysokości notowane dla części zachodniej - osiągając blisko $3 \mathrm{~m}$ n.p.m. Licznie występujące

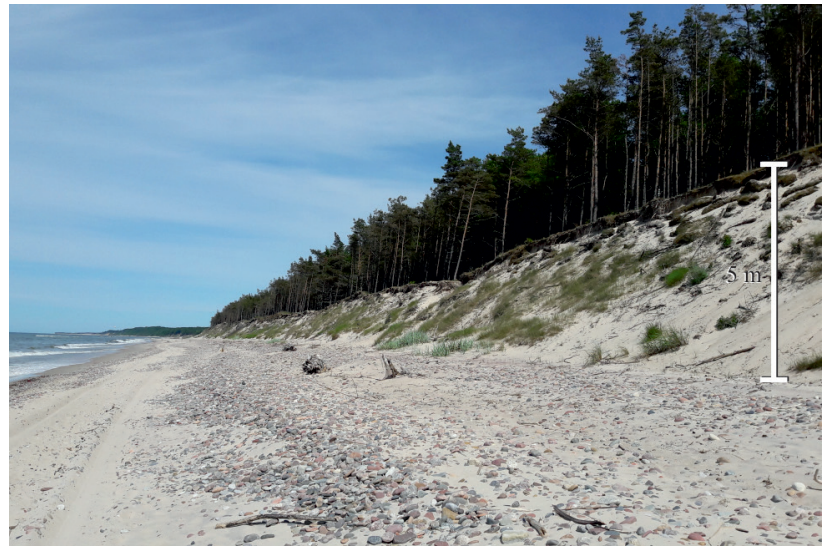

Ryc. 13. Brzeg w rejonie 228,3 km UM, widok ku wschodowi (fot. J. Frydel, 2016)

Fig. 13. Coast near 228.3 chainage $\mathrm{km}$, view to the east (photo J. Frydel, 2016) w tym rejonie otoczaki $(<64 \mathrm{~mm})$ i głaziki $(>64 \mathrm{~mm})$ wyznaczają zasięg oddziaływania fal sztormowych (ryc. 13). Źródłami zasilania w materiał grubookruchowy są zarówno osady zawierające gliny zwałowe położone dalej na zachód, jak i rozmywana platforma abrazyjna (Dobrzyński 1998). Natomiast skierowany ku wschodowi potok rumowiska wzdłużbrzegowego okresowo może ulegać regeneracji w odległości nawet 3-4,5 km na wschód od falochronu portu w Ustce, gdzie widoczna jest druga rewa w odległości 100-150 m od linii brzegowej.

Wysokość klifu w Orzechowie jest zmienna. Przebieg korony w zachodniej części przeważnie obejmuje przedział od kilkunastu do $20 \mathrm{~m}$, podczas gdy po przeciwnej stronie Orzechówki górna krawędź jest zdecydowanie niższa, w zakresie od kilku do kilkunastu metrów, przy jednoczesnym zachowaniu bardzo zbliżonej ekspozycji zboczy klifu (ryc. 14). Podstawa klifu w zachodniej części nie przekracza wysokości 2 m n.p.m. Profil plaży w dniu 8.06.2016 r. jest zmienny w przestrzeni, jednak dość szeroki (do $45 \mathrm{~m}$ ). Dla udokumentowanych zobrazowań szerokość plaży W części E jest natomiast zdecydowanie mniejsza. Stopniowo rośnie ku wschodowi od $10 \mathrm{~m}$ do przeszło $20 \mathrm{~m}$. Podstawa klifu/wydmy nie przekracza rzędnej 3 m n.p.m. Budowa geologiczna jest silnie urozmaicona. W zachodniej części występują miąższe pokrywy piaszczyste warunkujące powstawanie osypisk, jak również osady ilaste i mułkowe umożliwiające powstawanie osuwisk. W części wschodniej dominują zsuwy i osypiska, a lokalnie też niewielkie obrywy.

Analiza NMT wskazuje, że górna krawędź klifu podlega największej erozji w miejscach o największej elewacji, odpowiadających zboczom, w których profilu notowane są miąższe pokrywy piaszczyste (ryc. 15). Można na tej podstawie wnioskować, że odporność brzegów poza wysokością klifu jest definiowana budową geologiczną warunkującą powstawanie określonych ruchów masowych, a poza abrazją istotny

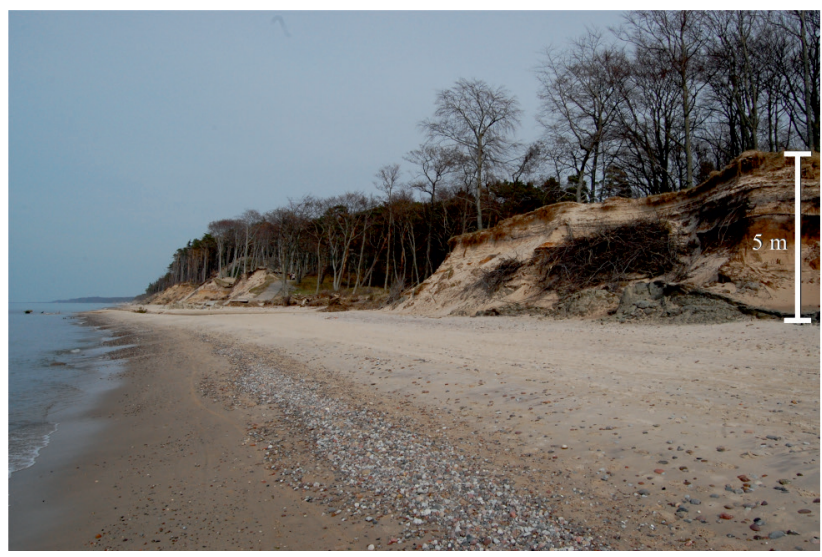

Ryc. 14. Klif w rejonie ujścia rzeki Orzechówki (fot. J. Frydel, 2016)

Fig. 14. The cliff near the Orzechówka river outlet (photo J. Frydel, 2016) 


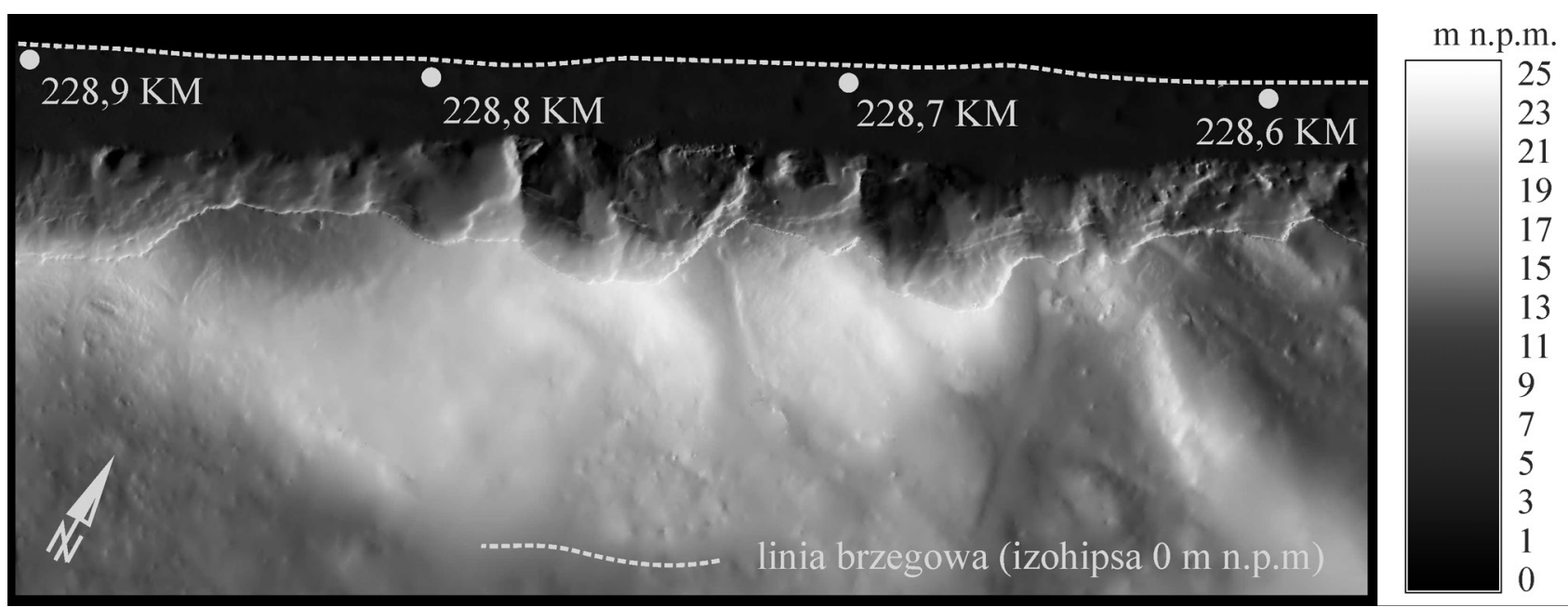

Ryc. 15. Fragment CMW lądu w skali barw odpowiadającej wysokościom terenu w m n.p.m.

Fig. 15. Fragment of land represented by DEM with a scale bar corresponding to the height of the terrain in $\mathrm{m}$ a.s.l.

wpływ na erozję zboczy wywiera deflacja, która inicjowana jest przy (zmierzonych in-situ) prędkościach wiatru powyżej $5-6 \mathrm{~m} \mathrm{~s}^{-1}$.

Konstrukcja przyczynowo-skutkowego modelu wykorzystującego ilościowe i jakościowe powiązania wielkości i tempa erozji z czynnikami wymuszającymi jest niezbędna dla właściwego planowania przestrzennego w strefie brzegowej morza. Jednak przy założeniu utrzymania obecnego tempa wzrostu poziomu morza, zbliżonej intensywności sztormów, budowie geologicznej, rzeźbie terenu i dotychczasowym stopniu antropopresji prognozowaną wielkość erozji przedstawiono na rycinie 10 . Na tej podstawie można oszacować m.in., że bezpośrednie zagrożenie dla ośrodka szkoleniowo-wypoczynkowego, należącego do Fundacji Pomocy Wzajemnej Barka, może wystąpić już za niespełna 50 lat.

\section{Dyskusja}

Tempo recesji klifów jest związane ze znaczną zmiennością w czasie i przestrzeni. Szybkość erozji klifu w Orzechowie w latach 60. i 70. XX w. osiągała jedne z najwyższych wartości na polskim wybrzeżu. Określona na podstawie profilowań poprzecznych dochodziła do wartości $\mathrm{w}$ przedziale $1,0-2,3 \mathrm{~m} \mathrm{a}^{-1}$ (Subotowicz 1982). Powyższy zakres odpowiada tempu recesji w odniesieniu do linii brzegowej w skali stulecia (1875-1979), określonej przez Zawadzką-Kahlau (1999) na około 1,6 $\mathrm{m} \mathrm{a}^{-1}$. Z kolei w niniejszej pracy prędkości recesji klifów (tab. 2) stanowią pochodną wielkości erozji (ryc. 10) odniesionej do przebiegu linii korony klifu, które w latach 2000-2011 mogło sięgać nawet 4,6 $\mathrm{m} \mathrm{a}^{-1}$. Tak wysoka wartość może być potencjalnie związana $z$ niedokładnościami wykorzystanych materiałów kartograficznych. Jednakże tempo erozji zachodniego odcinka klifu w Orzechowie określone na podstawie pomiarów TLS dla lat 2011-2016 wyniosło 2,1 $\mathrm{m} \mathrm{a}^{-1}$. Dla porównania średnie tempo erozji wybrzeża klifowego wyspy Wolin, ustalone dla lat 1985-2012, w zależności od lokalizacji odcinka badawczego było równe od 0,14 do 0,35 $\mathrm{m} \mathrm{a}^{-1}$ (Kostrzewski i in. 2015). Podana wartość jest nawet o rząd wielkości niższa niż w przypadku klifu w Orzechowie. Jedną z głównych przyczyn może stanowić różnica wysokości pomiędzy klifami, która w przypadku wyspy Wolin dochodzi do $60 \mathrm{~m}$ n.p.m., podczas gdy w Orzechowie maksymalnie 20 m n.p.m.

Wyznaczenie wielkości recesji klifów warunkowanej antropopresją (Dudzińska-Nowak 2015), czynnikami hydro-meteorologicznymi - przede wszystkim wezbraniami sztormowymi (Kostrzewski, i in. 2015), budową geologiczną (Uścinowicz i in. 2014), ruchami masowymi, w tym osuwiskami (Kramarska i in. 2011), nachyleniem (Zawadzka-Kahlau 1999) i budową geologiczną przybrzeża (Subotowicz 1982) - jest krokiem w stronę konstrukcji modelu stochastycznego. W szerszym ujęciu czasowym rozpoznanie maksymalnego uśrednionego tempa erozji klifów Zatoki Usteckiej (od środkowego holocenu) wymaga rozwinięcia badań przybrzeża przeprowadzonych przez Szeflera i in. (2015). Szczegółowe badania tego rejonu zostały zaplanowane $\mathrm{w}$ ramach cyklicznego zadania Państwowej Służby Geologicznej realizowanej przez PIG-PIB, jakim jest „Kartografia 4D w strefie brzegowej południowego Bałtyku”.

\section{Podsumowanie}

Badany obszar znamionuje duża różnorodność litologiczna i morfologiczna. Przedstawiona w artykule metoda znalazła zastosowanie do opisu morfodynamiki 
wybrzeża wysokiego, w tym jednoznacznego wyznaczenia wielkości i tempa erozji klifów w wieloleciu 2011-2016. Analizy morfometryczne pozwoliły na wykrycie widocznego w różnych skalach czasowych trendu, obrazującego spadek wielkości i tempa erozji $\mathrm{ku}$ wschodowi. Tendencja odzwierciedla stopniowe wygaszanie zasięgu wpływu falochronów portowych w Ustce, różnice w budowie geologicznej i przebiegu rzędnej podstawy klifu (wysokości plaży). Pełna diagnoza zagrożeń na tym obszarze wymaga również rozpoznania geomorfologii strefy przybrzeża i warunków hydro-meteorologicznych dla przyległego akwenu. Uzyskane wyniki pozwalają jednak na oszacowanie przyszłego tempa erozji na poziomie $2 \mathrm{~m} \mathrm{a}^{-1}$ dla części zachodniej i $1 \mathrm{~m} \mathrm{a}^{-1}$ dla części wschodniej, przy założeniu występowania zbliżonych aktywnych i pasywnych czynników warunkujących erozję.

\section{Podziękowania}

Badania zostały sfinansowane $z$ funduszy przeznaczonych na działalność statutową PIG-PIB (granty wewnętrzne nr 61-2701-1401-00-0, nr 61-3506-150200-0). Autorzy dziękują również Urzędowi Morskiemu w Słupsku za udostępnione materiały ze strefy brzegowej. Ponadto składają serdeczne podziękowania Recenzentom za wnikliwą analizę tekstu i cenne uwagi, które przyczyniły się do znaczącego udoskonalenia manuskryptu.

\section{Bibliografia}

Bohdziewicz L., 1963. Przegląd budowy geologicznej i typów polskich wybrzeży. Materiały do Monografii Polskiego Brzegu Morskiego 5.

Carpenter N.E., 2014. Development of an Integrated Soft Cliff Model to Determine the Impacts of Environmental and Climatic Change on Coastal Recession. PhD Thesis, University of Southampton: 1-290.

Cyberski J., 2011. Climate, hydrology and hydrodynamics of the Baltic Sea. W: S. Uścinowicz (red.), Geochemistry of Baltic Sea surface sediments. Warszawa: 55-65.

Dobrzyński S., 1998. Współczesny rozwój brzegu morskiego w świetle badań litologicznych (na odcinku Jarosławiec-Czołpino). Wyższa Szkoła Pedagogiczna w Słupsku.

Dudzińska-Nowak J., 2015. Metody ochrony zachodniego wybrzeża Polski i ich wpływ na zmiany brzegu w latach 1938-2011. Szczecin.

Florek W., Florek E., 1995. Man versus the eustatic impact on shoreline development at Ustka (Poland). W: M.G. Healy, J.P. Doody (red.), Directions in European Coastal Management. Samara Publishing Ltd., Cardigan: 243-251.

Florek W., Kaczmarzyk J., Majewski M., Olszak I.J., 2008. Zmiany rzeźby klifu w rejonie Ustki jako efekt warunków litologicznych oraz procesów ekstremalnych i przeciętnych. Landform Analysis 7: 53-68.

Florek W., Kaczmarzyk J., Majewski M., Schiefelbein L., 2013. Efektywność abrazji na wschód od Ustki. W: A. Kostrzewski,
Zb. Zwoliński, M. Winowski (red.), Geoekosystem wybrzeży morskich. 2. Poznań-Biała Góra: 36-39.

Frydel J., Mil L., Przyłucka M., Szarafin T., 2017. Tempo erozji klifów zachodniej części Zatoki Usteckiej w rejonie Orzechowa. W: A. Kostrzewski, M. Winowski (red.), Geoekosystem wybrzeży morskich. 3. Poznań-Biała Góra: 8-14.

Jurys L., Kaulbarsz D., Masłowska M., Michałowska M., Zaleszkiewicz L., 2006. Budowa geologiczna klifów wybrzeża polskiego na odcinku od Orłowa do Ustki. Arch. PIG - PIB, Gdańsk.

Klimaszewski M., 1981. Geomorfologia. Wydawnictwo Naukowe PWN, Warszawa.

Kolander R., Morche D., Bimböse M., 2013. Quantification of moraine cliff coast erosion on Wolin Island (Baltic Sea, northwest Poland). Baltica 26(1):37-44. DOI:10.5200/baltica.2013.26.04

Kondracki J., 2009. Geografia regionalna Polski. Wydawnictwo Naukowe PWN, Warszawa.

Kostrzewski A., Zwoliński Zb., Winowski M., Tylkowski J., Samołyk M., 2015. Cliff top recession rate and cliff hazards for the sea coast of Wolin Island (Southern Baltic). Baltica 28(2): 109-120. DOI: 10.5200/baltica.2015.28.10.

Kramarska R., Frydel J., Jegliński W., 2011. Zastosowanie metody naziemnego skaningu laserowego do oceny geodynamiki wybrzeża na przykładzie Klifu Jastrzębiej Góry. Biuletyn PIG - PIB 446: 101-108.

Łęczyński L., Kubowicz-Grajewska A., 2013. Studium przypadku: Klif Orłowski. W: T. Łabuz (red.), Sposoby ochrony brzegów morskich i ich wpływ na środowisko przyrodnicze polskiego wybrzeża Bałtyku - RAPORT. WWF Polska, Warszawa: 152-161.

Petrie G., Toth C., 2009. Introduction to Laser Ranging, Profiling, and Scanning. W: J. Shan, C. Toth (red.), Topographic Laser Ranging and Scanning, Boca Raton.

Rudowski S., 1962. Mikroformy strefy brzegowej Bałtyku w Polsce. Acta Geologica Polonica 12(4): 1-47.

Subotowicz W., 1982. Litodynamika brzegów klifowych wybrzeża Polski. Wrocław.

Szefler K., Rudowski S., Wróblewski R., Sitkiewicz P., 2015. Detailed geomorphological mapping of the sea bottom on the basis the Southern Baltic. Geobalcanica, Skopje: 51-55. DOI: 10.18509/GBP.2015.07.

Trenhaile A.S., 2010. Modeling cohesive clay coast evolution and response to climate change. Marine Geology 277: 11-20.

Uniejewska M., Nosek M., 1986. Objaśnienia do Szczegółowej mapy geologicznej Polski w skali 1:50 000, ark. Ustka. Wydawnictwa Geologiczne, Warszawa.

Uścinowicz G., Kramarska R., Kaulbarsz D., Jurys L., Frydel J., Przezdziecki P., Jegliński W., 2014. Baltic Sea coastal erosion; a case study from Jastrzębia Góra region. Geologos 20(4): 259268. DOI: 10.2478/logos-2014-0018.

WG UAM [Wydział Nauk Geograficznych i Geologicznych Uniwersytetu im. Adama Mickiewicza w Poznaniu], 2016. Mapa topograficzna w skali 1:25 000, Neu-Strand, godło 214 (1367) oraz Stolpmünde, godło 265 (1467), 1889. Online: http://mapy. amzp.pl/tk25 list.cgi? show $=1367$; sort $=w-15.12 .2016$.

Wężyk P., 2006. Wprowadzenie do technologii skaningu laserowego w leśnictwie. Roczniki Geomatyki 4(4): 119-132.

Wiłun Z., 2007. Zarys geotechniki. Wydawnictwa Komunikacji i Łączności.

Zachowicz J., Dobracki R., 2003. Geologiczne warunki ochrony i kształtowania południowego brzegu Bałtyku oraz obszarów ujściowych Odry i Wisły. Etap III. Mapa geodynamiczna polskiej strefy brzegowej Bałtyku w skali 1:10 000 wraz z objaśnieniami; arkusze: Ustka (25), Dębina (26). Centralne Archiwum Geologiczne PIG - PIB OGM.

Zawadzka-Kahlau E., 1999. Tendencje rozwojowe polskich brzegów Bałtyku południowego. Gdańskie Towarzystwo Naukowe, Gdańsk. 